\title{
Perbandingan Kadar Antioksidan Total pada Kanker Serviks Stadium Lanjut Sebelum dan Setelah Kemoterapi
}

\author{
Nur Amin Wahidji, Syahrul Rauf, Nuraini Abidin \\ Departemen Obstetri dan Ginekologi, Fakultas Kedokteran, Universitas Hasanuddin, Indonesia \\ Korespondensi: Nur Amin Wahidji, Email: wahidji_amin87@yahoo.com
}

\begin{abstract}
Abstrak
Tujuan: Membandingkan kadar antioksidan total pada penderita kanker serviks stadium lanjut sebelum dan setelah kemoterapi.

Metode: Merupakan penelitian studi kohort prospektif yang dilakukan di Badan Layanan Umum (BLU) Rumah Sakit Wahidin Sudirohusodo Perawatan onkologi-ginekologi Lontara 4 bawah dan Unit Penelitian Rumah Sakit Perguruan Tinggi Negeri Universitas Hasanuddin. dari perode tanggal 1 Oktober 2019-30 September 2020. Sampel penelitian adalah semua penderita kanker serviks stadium lanjut yang memenuhi kriteria inklusi. Data yang diambil adalah data primer menggunakan questionnaire serta pemeriksaan kadar Anti Oksidan Total dengan metode ELISA. Data yang diperoleh dianalisis dengan menggunakan program komputer SPSS 25.0, Microsoft Excel dan Microsoft Word.

Hasil: Terdapat 34 orang sampel penelitian menderita kanker serviks stadium lanjut yang mendapatkan kemoterapi 3 seri. Stadium 2B memiliki perbedaan rerata antioksidan yang signifikan secara statistik. Tipe adenokarsinoma, jenis diferensiasi kategori sedang dan kategori tidak ada keterangan memiliki perbedaan kadar antioksidan yang signifikan secara statistik. Terdapat perbedaan rerata kadar antioksidan total antara sebelum dan sesudah dilakukan kemoterapi dengan $\mathrm{p}<0,05$.

Kesimpulan: Terdapat penurunan bermakna kadar antioksidan total sebagai penanda stres oksidatif pada pasien kanker serviks stadium lanjut yang menjalani prosedur kemoterapi.
\end{abstract}

Kata kunci: Kadar Antioksidan, Kanker Serviks Stadium Lanjut, Kemoterapi

\section{Comparison Total Antioxidant Levels in Patients with Advanced Cervical Cancer Prior and Post-Chemotherapy}

\begin{abstract}
Purpose: Comparing total antioxidant levels in patients with advanced cervical cancer prior and postchemotherapy.

Method: This is a prospective cohort study underwent at the Public Service Agency of Wahidin Sudirohusodo Hospital, Lontara 4 Bawah oncology-gynecology care and Research Unit of State University Hospital, Hasanuddin University from October 1st, 2019 to September 30th, 2020. The study sample being used was all patients with advanced cervical cancer who met the inclusion criteria. The data extracted were primary data using a questionnaire, as well as the examination of Total Anti-Oxidant levels using the ELISA method. The data obtained were analyzed further using a computer program SPSS 25.0, Microsoft Excel, and Microsoft Word.

Outcome: Approximately 34 study samples were suffering from advanced cervical cancer who undergone 3 series of chemotherapy. Stage $2 B$ revealed a statistically significant difference in antioxidant level. The type of adenocarcinoma, the type of the moderate category differentiation, and the no description category had statistically significant differences in antioxidant levels. It was identified that there was a difference in the mean total antioxidant level between prior and post-chemotherapy with $p<0.05$.

Conclusion: There was a significant decline in the total antioxidant levels to indicate a sign of oxidative stress in advanced cervical cancer patients who are undergoing chemotherapy procedures.
\end{abstract}

Key word: Antioxidant Levels, Advanced Cervical Cancer, Chemotherapy 


\section{Pendahuluan}

Kanker serviks menempati peringkat terbanyak ketiga dengan 500.000 kasus baru setiap tahun di seluruh dunia dan lebih dari $90 \%$ diantaranya terjadi di negara berkembang. ${ }^{(1,2)}$ Kanker serviks menyebabkan kematian lebih dari 270.000 kasus dimana lebih dari $85 \%$ terjadi di negara - negara berpenghasilan rendah dan menengah termasuk Indonesia. ${ }^{(2)}$ Angka kejadian kanker serviks di Indonesia tahun 2015 terdapat 98.692 kasus. Pasien kanker serviks memiliki survival rate dalam 5 tahun secara keseluruhan $84 \%$ di semua tahapan. Namun, tingkat kelangsungan hidup selanjutnya berkurang menjadi $17 \%$, jika kanker berhasil bermetastasis ke organ jauh di dalam tubuh. ${ }^{(3)}$

Kemoterapi menjadi modalitas penanganan kanker serviks yang dapat menyebabkan toksisitas dan stres oksidatif, sehingga penggunaan antioksidan dapat memberikan efek perlindungan pada sel-sel sehat. Namun masih ada kontroversi tentang penggunaan antioksidan selama pengobatan onkologi. Oleh karena itu, penelitian bertujuan membandingkan kadar antioksidan total pada penderita kanker serviks stadium lanjut sebelum dan setelah kemoterapi.

\section{Metode Penelitian}

Penelitian ini merupakan studi kohort prospektif, yang mana pengukuran variabel dilakukan pada saat sebelum dilakukan kemoterapi kemudian diukur kembali setelah dilakukan 3 kali kemoterapi sesuai dengan pedoman nasional pelayanan kedokteran kanker serviks. ${ }^{(4)}$

Penelitian ini dilakukan di BLU Rumah Sakit Wahidin Sudirohusodo Perawatan onkologi-ginekologi Lontara 4 bawah dan Unit Penelitian Rumah Sakit Perguruan Tinggi Negeri Universitas Hasanuddin. Pemeriksaan sampel dilakukan Laboratorium Novartis Eijkman Hasanuddin Research
Initiative (NECHRI) Universitas Hasanuddin Makassar untuk pemeriksaan kadar antioksidan total. pelaksanaan penelitian ini diambil dari perode tanggal 1 Oktober 2019 - 30 September 2020.

Populasi penelitian adalah semua pasien yang didiagnosis sebagai Kanker serviks stadium lanjut BLU Rumah Sakit Wahidin Sudirohusodo Perawatan onkologiginekologi Lontara 4 bawah.

Sampel adalah semua penderita kanker serviks stadium lanjut yang memenuhi kriteria inklusi dan telah menandatangani surat persetujuan.

Kriteria inklusi: bersedia ikut serta dalam kegiatan penelitian dan menandatangani surat persetujuan penelitian, terdiagnosis pasti kanker serviks secara histopatologis, usia 20 - 60 tahun, tidak pernah menjalani operasi pengangkatan rahim, telah menyelesaikan kemoterapi 3 kali, tidak menderita keganasan lain seperti: kanker kolon, kanker hati, kanker paru dan kanker payudara

Kriteria eksklusi: pernah menjalani kemoradiasi sebelumnya, memiliki riwayat infeksi lokal dan sistemik, sampel serum darah mengalami lisis, subyek mengundurkan diri dari penelitian.

Besarnya sample (n) yang diperlukan dihitung dengan rumus simple random sampling: $\mathrm{n}$ adalah perkiraan jumlah sampel. $\mathrm{N}$ adalah 72 (jumlah penderita kanker serviks baru dalam 1 tahun). $\mathrm{P}$ adalah 0,8 (proporsi). Q adalah $1-\mathrm{P}=0,2 . \mathrm{Z}$ adalah 1,96. $\mathrm{D}$ adalah 0,1 (tingkat ketelitian).

Berdasarkan rumus di atas, jumlah sampel minimal penelitian ini adalah 33,4 maka jumlah sampel penelitian ini adalah dibulatkan menjadi 34 sampel.

Data primer yang diperoleh dengan menggunakan questionaire, kemudian catat hasil pemeriksaan fisik dan laboratorium pada lembar yang disediakan. Serta pemeriksaan kadar antioksidan total dengan metoda ELISA.

Kadar antioksidan total merupakan 
pemeriksaan untuk mengukur kapasitas dan aktivitas total antioksidan yang terdapat di dalam tubuh. Setelah dilakukan pengumpulan dan pencatatan data primer, data yang diperoleh diorganisasikan dan diolah dengan menggunakan program komputer Statistical Product and Service Solution (SPSS) 25.0, Microsoft Excel dan Microsoft Word.

Perbandingan kadar anti oksidan total sebelum dan setelah kemoterapi diuji dengan uji Wilcoxon dengan tingkat kemaknaan $p<0,05$. Pengolahan data dilakukan dengan SPSS 25.0

Penelitian ini dilaksanakan berdasarkan surat rekomendasi persetujuan etik 22947/ UN4.6.7/PT.01.04/2019 yang diberikan oleh Komite Etik Penelitian Kesehatan Fakultas Kedokteran Universitas Hasanuddin, Rumah Sakit Perguruan Tinggi Negeri Universitas Hasanuddin, dan BLU Rumah Sakit Wahidin Sudirohusodo.

Peneliti melakukan wawancara terhadap pasien kanker serviks sebagai subjek penelitian. Hasil wawancara dicatat formulir penelitian. Dilakukan pemeriksaan fisik umum dan tanda-tanda vital. Sampel darah vena diambil sebanyak 2,5 cc. Sampel darah disentrifus $3000 \mathrm{rpm}$ selama 15 menit untuk memperoleh serum. Serum yang belum diperiksa disimpan dalam lemari pendingin suhu $-20^{\circ} \mathrm{C}$ di Laboratorium Unit Penelitian RS UNHAS. Pemeriksaan kadar anti oksidan total pada serum dilakukan dengan mengukur kadar kadar anti oksidan total menggunakan Human Total Anti oxidant Status ELISA kit - 96T (Cat. No. E1599Hu, Bioassay Technology Laboratory, Shanghai, China) dengan metode ELISA.

\section{Hasil}

Diperoleh 34 orang sampel penelitian menderita kanker serviks stadium lanjut yang mendapatkan kemoterapi 3 seri. Terdiri dari 12 penderita stadium IIB dan 22 penderita stadium III (10 penderita stadium IIIA,
12 penderita stadium IIIB). Selama masa penelitian ini, tidak didapatkan sampel dengan kanker serviks stadium III C dan IV. Usia responden, usia $\leq 45$ tahun memiliki proporsi tertinggi yaitu sebesar $61.8 \%$.

Berdasarkan stadium, Stadium 2B dan 3B masing-masing sebanyak 12 responden $(35.3 \%)$ sedangkan stadium 3A sebanyak 10 responden (29.4\%). Untuk tipe adenokarsinoma sebanyak 10 responden (29.4\%) dan tipe squamous cell carcinoma sebanyak 24 responden (70.6\%). Sedangkan berdasarkan diferensiasi, proporsi tertinggi adalah kategori sedang sebanyak 17 responden $(50.0 \%)$.

Untuk parameter hemopoetik mengalami penurunan setelah dilakukan kemoterapi yaitu: Hemoglobin sebelum kemoterapi 13,10 setelah dilakukan kemoterapi menjadi 11,20, eritrosit sebelum dilakukan kemoterapi 4,74 setelah kemoterapi menjadi 4,23, demikian juga dengan leukosit sebelum dilakukan kemoterapi 8,34 setelah kemoterapi menjadi 7,29 , serta trombosit sebelum dilakukan kemoterapi 300,50 setelah dilakukan kemoterapi menjadi 176.

\section{Tabel 1 Distribusi Karakteristik Umum} Sampel Penelitian

\begin{tabular}{lc}
\hline Karakteristik & $\mathbf{n}=\mathbf{3 4}$ \\
\hline Kategori Usia, n(\%) & \\
$\leq 45$ tahun & $21(61.8)$ \\
$>45$ tahun & $13(38.2)$ \\
Paritas, n(\%) & \\
Nulipara & $1(2.9)$ \\
Primipara & $2(5.9)$ \\
Multipara & $29(85.3)$ \\
Grandemultipara & $2(5.9)$ \\
Stadium, n(\%) & \\
Stadium 2B & $12(35.3)$ \\
Stadium 3A & $10(29.4)$ \\
Stadium 3B & $12(35.3)$ \\
Jenis, n(\%) & \\
Tipe adenokarsinoma & $10(29.4)$
\end{tabular}




\begin{tabular}{|c|c|}
\hline $\begin{array}{l}\text { Tipe squamous cell } \\
\text { carsinoma }\end{array}$ & $24(70.6)$ \\
\hline \multicolumn{2}{|l|}{ Diferensiasi, n(\%) } \\
\hline Baik & $2(5.9)$ \\
\hline Sedang & $17(50.0)$ \\
\hline Buruk & $2(5.9)$ \\
\hline Tidak ada keterangan & $13(38.2)$ \\
\hline $\begin{array}{l}\text { Antioksidan, median } \\
\text { (rentang) }\end{array}$ & $4,77(3,42-14,85)$ \\
\hline \multicolumn{2}{|l|}{ Sebelum Kemoterapi } \\
\hline Sesudah Kemoterapi & $3,78(2,31-5,67)$ \\
\hline \multicolumn{2}{|l|}{$\begin{array}{l}\text { Hemoglobin, median } \\
\text { (rentang) }\end{array}$} \\
\hline Sebelum Kemoterapi & $13,10(11,90-14,40)$ \\
\hline Sesudah Kemoterapi & $11,20(10,50-13,60)$ \\
\hline \multicolumn{2}{|l|}{$\begin{array}{l}\text { Eritrosit, median } \\
\text { (rentang) }\end{array}$} \\
\hline Sebelum Kemoterapi & $4,74(4,22-5,73)$ \\
\hline Sesudah Kemoterapi & $4,23(3,18-5,22)$ \\
\hline \multicolumn{2}{|l|}{$\begin{array}{l}\text { Leukosit, median } \\
\text { (rentang) }\end{array}$} \\
\hline Sebelum Kemoterapi & $8,34(6,52-10,59)$ \\
\hline Sesudah Kemoterapi & $7,29(6,18-9,19)$ \\
\hline \multicolumn{2}{|l|}{$\begin{array}{l}\text { Trombosit, median } \\
\text { (rentang) }\end{array}$} \\
\hline Sebelum Kemoterapi & $300,50(159-410)$ \\
\hline Sesudah Kemoterapi & $176(117-287)$ \\
\hline Jumlah & 34 \\
\hline
\end{tabular}

Pada tabel 2 berdasarkan stadium, Stadium 2B sebelum dilakukan kemoterapi rerata sebesar 5.53 dan setelah dilakukan kemoterapi rerata sebesar 3.53, dari hasil uji statistik diperoleh nilai $\mathrm{p}(0.002)<0.05$ yang berarti terdapat perbedaan rerata antioksidan antara sebelum dan sesudah dilakukan kemoterapi. Stadium 3A sebelum dilakukan kemoterapi rerata sebesar 5.89 dan setelah dilakukan kemoterapi rerata sebesar 3.99, dari hasil uji statistik diperoleh nilai $\mathrm{p}(0.005)$ $<0.05$ yang berarti terdapat perbedaan rerata antioksidan antara sebelum dan sesudah dilakukan kemoterapi.
Tabel 2 Kadar Antioksidan Total Berdasarkan Stadium Pasien Kanker Serviks Sebelum Dan Sesudah Kemoterapi

\begin{tabular}{cccc}
\hline Stadium & $\begin{array}{c}\text { Sebelum } \\
(\mathbf{m e a n} \pm \text { SD) }\end{array}$ & $\begin{array}{c}\text { Sesudah } \\
(\mathbf{m e a n} \pm \mathbf{S D})\end{array}$ & $\mathbf{p}$ \\
\hline II B & $5.53 \pm 2.99$ & $3.53 \pm 0.67$ & 0.002 \\
III A & $5.89 \pm 2.44$ & $3.99 \pm 0.92$ & 0.005 \\
III B & $6.13 \pm 3.48$ & $3.87 \pm 0.85$ & 0.002 \\
Uji Wilcoxon & & &
\end{tabular}

Pada stadium 3B sebelum dilakukan kemoterapi rerata sebesar 6.13 dan setelah dilakukan kemoterapi rerata sebesar 3.87, dari hasil uji statistik diperoleh nilai $p(0.002)$ $<0.05$ yang berarti terdapat perbedaan rerata antioksidan antara sebelum dan sesudah kemoterapi.

Tabel 3 Kadar Antioksidan Total Berdasarkan Tipe Sel Pasien Kanker Serviks Sebelum dan Sesudah Kemoterapi

\begin{tabular}{lccc}
\hline \multicolumn{1}{c}{ Tipe Sel } & $\begin{array}{c}\text { Sebelum } \\
(\mathbf{m e a n} \pm \text { SD) }\end{array}$ & $\begin{array}{c}\text { Sesudah } \\
(\mathbf{m e a n} \pm \text { SD) }\end{array}$ & $\mathbf{p}$ \\
\hline $\begin{array}{l}\text { Tipe adenokarsi- } \\
\text { noma }\end{array}$ & $6.62 \pm 3.72$ & $3.95 \pm 0.93$ & 0.005 \\
$\begin{array}{l}\text { Tipe squamous } \\
\text { cell carsinoma }\end{array}$ & $6.62 \pm 2.59$ & $3.72 \pm 0.77$ & 0.000 \\
$\begin{array}{l}\text { Uj Wilcoxon } \\
\end{array}$ & & & \\
\end{tabular}

Tabel 3 berdasarkan jenis, tipe adenokarsinoma sebelum dilakukan kemoterapi rerata sebesar 6.62 dan setelah dilakukan kemoterapi rerata sebesar 3.95, dari hasil uji statistik diperoleh nilai $p(0.005)$ $<0.05$ yang berarti terdapat perbedaan rerata antioksidan antara sebelum dan sesudah dilakukan kemoterapi. Tipe squamous cell carsinoma, sebelum dilakukan kemoterapi rerata sebesar 5.53 dan setelah dilakukan rerata sebesar 3.72, dari hasil uji statistik diperoleh nilai $\mathrm{p}(0.000)<0.05$ yang berarti terdapat perbedaan rerata antioksidan antara 
sebelum dan sesudah dilakukan kemoterapi.

\section{Tabel 4 Kadar Antioksidan Total Berdasarkan Diferensiasi Sel Pasien Kanker Serviks Sebelum Dan Sesudah Kemoterapi}

\begin{tabular}{llll}
\hline $\begin{array}{c}\text { Diferensiasi } \\
\text { sel }\end{array}$ & $\begin{array}{c}\text { Sebelum } \\
(\mathbf{m e a n} \pm \text { SD) }\end{array}$ & $\begin{array}{c}\text { Sesudah } \\
(\mathbf{m e a n} \pm \text { SD) }\end{array}$ & p \\
\hline Baik & $4.49 \pm 0.71$ & $3.80 \pm 1.03$ & 0.180 \\
Sedang & $6.60 \pm 3.64$ & $3.99 \pm 0.95$ & 0.000 \\
Buruk & $8.82 \pm 4.54$ & $3.74 \pm 0.88$ & 0.180 \\
\hline Oji Wilcoxon & & &
\end{tabular}

Tabel 4 berdasarkan diferensiasi, kategori baik sebelum dilakukan kemoterapi rerata sebesar 4.49 dan setelah dilakukan kemoterapi rerata sebesar 3.80, dari hasil uji statistik diperoleh nilai $\mathrm{p}(0.180)>0.05$ yang berarti tidak terdapat perbedaan rerata antioksidan antara sebelum dan sesudah dilakukan kemoterapi. Kategori sedang, sebelum dilakukan kemoterapi rerata sebesar 6.60 dan setelah dilakukan kemoterapi rerata sebesar 3.99, dari hasil uji statistik diperoleh nilai $\mathrm{p}(0.000)<0.05$ yang berarti terdapat perbedaan rerata antioksidan antara sebelum dan sesudah dilakukan kemoterapi. Kategori buruk sebelum intervensi rerata sebesar 8.82 dan setelah dilakukan kemoterapi rerata sebesar 3.74, dari hasil uji statistik diperoleh nilai $\mathrm{p}(0.180)>0.05$ yang berarti tidak terdapat perbedaan rerata antioksidan antara sebelum dan sesudah dilakukan kemoterapi.

Pada kategori tidak ada keterangan (Tabel 4), sebelum dilakukan kemoterapi rerata sebesar 4.62 dan setelah dilakukan kemoterapi rerata sebesar 3.52, dari hasil uji statistik diperoleh nilai $\mathrm{p}(0.000)<0.05$ yang berarti terdapat perbedaan rerata antioksidan antara sebelum dan sesudah dilakukan kemoterapi.

Tabel 5 dilakukan penggolongan kriteria kadar antioksidan total dengan batasan nilai $4 \mathrm{u} / \mathrm{L}$ berdasarkan kadar antioksidan total pada manusia normal sebesar 4-6 u/L. Berdasarkan hasil regresi logistik didapatkan bahwa baik pada kelompok setelah dilakukan kemoterapi dengan nilai antioksidan total rendah dan normal, diperoleh nilai $\mathrm{p}>0,05$ yang berarti tidak ada perbedaan bermakna secara statistik antara kedua kelompok tersebut. Sedangkan stadium III memiliki OR 4,714 artinya stadium III mempunyai peluang 4,7 kali lipat mengalami antioksidan total yang lebih rendah dari stadium II. Jenis diferensiasi sel yang "Buruk" memiliki OR 8,478 artinya Jenis diferensiasi sel yang "Buruk" mempunyai peluang 8,4 kali lipat mengalami antioksidan total yang lebih rendah dibandingkan diferensiasi sedang dan baik.

Tabel 5 Hubungan Kadar Antioksidan Total Dengan Stadium, Jenis Sel Dan Derajat Diferensiasi

\begin{tabular}{|c|c|c|c|c|c|c|}
\hline & \multirow{2}{*}{$\begin{array}{c}\text { Variabel } \\
<4 \mathrm{u} / \mathrm{L} \\
\text { (n: 34) } \%\end{array}$} & \multicolumn{2}{|c|}{ Post kemoterapi } & \multirow[b]{2}{*}{$\mathbf{P}$} & \multirow[b]{2}{*}{ OR } & \multirow[b]{2}{*}{ CI $95 \%$} \\
\hline & & $\begin{array}{c}\geq 4 \mathrm{u} / \mathrm{L} \\
(\mathrm{n}: 34) \%\end{array}$ & & & & \\
\hline \multirow[t]{3}{*}{ Stadium } & Stadium 2 & $9(75,0)$ & $3(25,0)$ & & 4,74 & $0,758-29,306$ \\
\hline & Stadium 3 & $1(45,5)$ & $12(54,5)$ & 0,195 & & \\
\hline & Tipe adenokarsinoma & $14(58,3)$ & $10(41,7)$ & & & \\
\hline \multirow[t]{3}{*}{ Jenis } & $\begin{array}{l}\text { Tipe squamous cell } \\
\text { carsinoma }\end{array}$ & $5(50,0)$ & $5(50,0)$ & 0,718 & 0,776 & $0,113-5,344$ \\
\hline & Tidak ada & $9(69,2)$ & $4(30,8)$ & & & \\
\hline & Baik & $1(50,0)$ & $1(50,0)$ & & 3,439 & $0,120-98,947$ \\
\hline \multirow[t]{2}{*}{ Diferensiasi } & Sedang & $8(47,1)$ & $9(62,9)$ & & 2,468 & $0,417-14,607$ \\
\hline & Buruk & $1(50,0)$ & $1(50,0)$ & 0,675 & 8,478 & $0,170-422,413$ \\
\hline
\end{tabular}




\section{Pembahasan}

Penelitian ini dilakukan dengan mengambil sampel sebanyak 34 orang penderita kanker serviks stadium lanjut. Pada tabel 1 memperlihatkan karakteristik umum seperti umur, paritas.

Angka prevalensi kanker serviks di Indonesia terjadi pada rentang usia 25 sampai 60 tahun. Telah banyak penelitian menemukan bahwa insidens kanker serviks pada usia muda makin meningkat. Hasil penelitian ini mendapatkan usia $\leq 45$ tahun memiliki proporsi tertinggi yaitu sebesar $61.8 \%$. $^{(5)}$

Menurut teori kejadian kanker serviks meningkat bersamaan dengan bertambahnya usia serta waktu mulai terinfeksi HPV sampai menjadi kanker invasif sebagai proses multistage karsinogenesis yang membutuhkan sekitar 10-20 tahun. Hal ini yang menjelaskan usia produktif merupakan salah satu risiko kanker serviks. ${ }^{(6)}$ Jumlah paritas yang banyak diperoleh pada karakteristik umum penelitian ini, yang merupakan faktor risiko untuk kanker serviks selain usia. Pada penelitian ini diperoleh $85 \%$ sample adalah multipara. Hal ini dikaitkan dengan perubahan sel yang terjadi pada SCC selama kehamilan akibat dari peningkatan hormon estrogen dan progesterone yang sangat tinggi. Perubahan kadar estrogen dan progesteron ini menyebabkan hiperplasia kelenjar mukosa serviks dan SCC, proliferasi sel basal secara tidak teratur demikian juga morfologi sel. Demikian juga penelitian De Boer di Indonesia yang menunjukkan paritas tinggi merupakan faktor risiko yang signifikan untuk kanker serviks. ${ }^{(7)}$ Penelitian lainnya di Indonesia menunjukkan perempuan dengan grande multipara berisiko 2,6 kali mengalami kanker serviks dibandingkan multipara $(\leq 4$ anak). ${ }^{(8)}$

Pada penelitian ini juga diperoleh kadar hemopetik yang mengalami penurunan setelah dilakukan kemoterapi. Parameter yang mengalami perubahan tersebut yaitu, hemoglobin, leukosit, eritrosit, dan trombososit. Hal ini dalam teori yang dikenal dengan istilah toksisitas hematologis. Di beberapa penelitian terdapat penurunan kadar hemopoetik sampai kadar di bawah normal, berupa anemia, trombositopenia, dan leukopenia. Anemia merupakan toksisitas yang paling sering terjadi, namun hal ini sulit dibedakan dengan perjalanan penyakit kanker serviks itu sendiri. ${ }^{(9)}$

Agent kemoterapi terutama golongan Platinum Based mempunyai efek sitotoksik dan radiosensitizer terhadap tumor. Sebagai dampaknya terbentuknya radikal bebas yang apabila jumlahnya berlebihan bersifat toksik, dan merusak sel - sel normal dalam tubuh termasuk sumsum tulang yang mengakibatkan penekanan sistem hemopoetik. Sistem hemopoetik berfungsi memproduksi hemoglobin, eritrosit, leukosit dan trombosit. Penurunan sel hemopoetik akan menurunkan kemampuan fagositosis terhadap sel kanker sehingga memperburuk prognosis. Hemoglobin menggambarkan kadar oksigen yang didistribusikan ke sel tubuh, leukosit menggambarkan sistem pertahanan tubuh, sedangkan trombosit menggambarkan sistem hemostasis. Sehingga pemberian antioksidan disarankan karena hasil oksidasi dari kemoterapi. ${ }^{(10)}$

Pada penelitian ini, secara umum didapatkan kadar antioksidan total serum yang rendah pada pasien kanker serviks stadium lanjut yang telah mendapatkan kemoterapi, yaitu sebesar 3,79 $\pm 0,81 \mathrm{U} / \mathrm{ml}$. Kadar ini lebih rendah dari kadar antioksidan total serum sebelum kemoterapi yakni 5,85 $\pm 2,95$ $\mathrm{U} / \mathrm{ml}$ dengan signifikansi statistik tinggi ( $p$ $<0,001)$. Hal ini menunjukkan kemoterapi mempengaruhi kadar antioksidan total serum pasien kanker serviks stadium lanjut.

Ada tiga parameter kanker serviks stadium lanjut saat yang dinilai pada penelitian ini, yaitu stadium, jenis sel, serta derajat diferensiasi. Pada stadium kanker serviks didapatkan stadium II lebih banyak dari stadium III. Hal ini berhubungan dengan 
gejala yang ditimbulkan oleh kanker seviks stadium awal hanya berupa keputihan yang berlebihan, sehingga penderita kanker serviks datang di stadium lanjut, yakni stadium II.

Berdasarkan pemeriksaan histopatologi dalam penelitian ini diperoleh proporsi tipe histologi squamous cell carcinoma (SCC) lebih banyak dibandingkan tipe adenocarcinoma. Secara statistik SCC 85 $90 \%$ sedangkan $10 \%$ adenokarsinoma. Hal ini dikaitkan dengan jenis histologi squamous cell carcinoma yang lebih banyak ditemukan pada usia 20 - 40 tahun. ${ }^{(11)}$

Pada penelitian ini diperoleh kadar antioksidan totalnya menurun setelah dilakukan kemoterapi di semua parameter stadium lanjut. Menurunnya kadar antioksidan ini mencerminkan peningkatan kadar stress oksidatif yang disebabkan oleh interaksi berbagai agen karsinogenik sehingga terbentuknya radikal bebas dalam jumlah banyak. Hal ini sesuai dengan teori bahwa pada kanker terdapat stres oksidatif endogen yang tinggi baik secara in vitro dan in vivo. ${ }^{(12)}$

Kemoterapi mempengaruhi kadar antioksidan total melalui efek langsung dan tidak langsung. Efek langsungnya yaitu kemoterapi secara langsung merusak molekul DNA pada jaringan target. Pada proses karsinogenesis, terjadi produksi radikal bebas yang berlebihan. Dalam kondisi normal, dalam tubuh terdapat mekanisme pertahanan tubuh untuk mengimbangi aktivitas radikal bebas yakni antioksidan. Ada banyak jenis antioksidan seperti antioksidan enzimatik catalase (CAT). Hal ini dapat terlihat dengan dengan semakin meningkatnya peroksidasi lipid selama kemoterapi yang sebanding dengan penurunan enzim ini. Ini yang menjadi asumsi bahwa CAT yang terpakai juga semakin banyak. Atau dengan kata lain Peningkatan produksi radikal bebas, menyebabkan penurunan aktivitas dari mekanisme pertahanan antioksidan. ${ }^{(12)}$

Efek tidak langsungnya adalah terjadinya pembentukan radikal bebas. Radikal bebas ini menyebabkan kerusakan sel baik secara langsung maupun melalui metabolit reaktifnya. Radikal bebas menginduksi peroksidasi lipid yang merupakan salah satu jenis ROS kemudian akan merusak membran sel, melalui interaksi kemoterapi dengan molekul air yang merupakan komponen utama tubuh. Interaksi radikal bebas ini menyebabkan kerusakan sel, bukan hanya sel tumor namun juga mengancam integritas dan kelangsungan hidup sel normal sekitarnya, serta memberikan risiko cedera pada jaringan normal yang dikenal dengan toksisitas kemoterapi. ${ }^{(12)}$

Peningkatan peroksidasi lipid menyebabkan penurunan antioksidan pada sirkulasi. Hal ini berkaitan dengan semakin meningkatnya peroksidasi lipid selama kemoterapi, sehingga antioksidan yang semakin banyak terpakai. Peningkatan produksi radikal bebas, penurunan aktivitas dari mekanisme pertahanan antioksidan atau kurangnya konsumsi antioksidan yang meningkat menyebabkan meningkatnya stres oksidatif. ${ }^{(12)}$

Pada penelitian ini diperoleh kadar antioksidan total pada stadium 2 dan 3 menurun setelah dilakukan kemoterapi. Penurunan kadar antioksidan yang bermakna setelah dilakukan kemoterapi ini terjadi karena rusaknya sel kanker dan sel normal oleh agen kemoterapi. Efek toksisitas dari kemoterapi ini menyebabkan tingginya jumlah radikal bebas dalam serum pasien yang telah mendapatkan kemoterapi. Radikal bebas yang merupakan atom atau molekul yang memiliki sebuah elektron yang tidak berpasangan di orbit luarnya (unpaired electron) dan memiliki reaktivitas tinggi serta kecenderungan membentuk radikal yang baru sehingga terjadi reaksi rantai (chain reaction) dan akan berhenti apabila dapat diredam (quenched) oleh antioksidan. Metabolit oksigen utama yang dihasilkan melalui reduksi satu elektron yang 
merupakan Reaktif Oksigen Spesies (ROS) yang terdiri dari superoksida $\left(\mathrm{O}^{-}\right)$, radikal bebas hidroksil $\left(\mathrm{OH}^{-}\right)$, hidrogen peroksida (H2O2), serta radikal peroksil $\left(\mathrm{RCOO}^{-}\right) .^{(12)}$

Untuk penurunan kadar antioksidan total setelah kemoterapi pada sel yang berdiferensiasi sedang didapatkan hasilnya bermakna dengan p 0,000 sedangkan pada diferensiasi baik dan buruk didaptkan hasil tidak bermakna dengan $\mathrm{p}$ 1,80. Hal ini diesebabkan oleh karena jumlah sampel kedua parameter sama - sama berjumlah 2 orang, sehingga setelah dilakukan uji statistik menghasilkan nilai $p$ yang sama. Walaupun secara statistik kedua parameter tersebut tidak bermakna, akan tetapi secara klinis dapat dijelaskan bahwa terjadi penurunan kadar antioksidan pada keduanya. Secara teori dijelaskan bahwa $\mathrm{Zn}$ digunakan untuk pertumbuhan sel dan juga berguna untuk menjaga keutuhan membran sel. Sehingga berpengaruh pada diferensiasi dari sel kanker. Sedangkan tembaga $(\mathrm{Cu})$ berinteraksi langsung dengan basa DNA di situs G-C. Pada penelitian yang lain penambahan tembaga ke DNA in vitro memperantarai kerusakan basa DNA yang lebih luas yang mendorong lebih banyak mutasi. Oleh karena itu, inaktivasi gen penekan tumor tertentu dapat menyebabkan inisiasi karsinogenesis dan diferensiasinya. ${ }^{(13)}$

Dari penelitian ini didapatkan bahwa koefiesien diferensiasi sel yang buruk, memiliki risiko 8,4 kali lebih rendah antioksidannya dibandingkan dengan koefisien diferensiasi sel baik dan sedang. Stadium 3 risiko 4,7 kali lebih rendah antioksidannya dibanding stadium 2. Dengan kata lain semakin buruk derajat diferensiasi selnya maka semakin rendahkadarantioksidan totalnya. Demikian pula semakin tinggi stadium kanker serviks maka semakin rendah kadar antioksidan totalnya. Kedua parameter diatas dapat dijelaskan bahwa penurunan kadar antioksidan dalam darah oleh karena peningkatan radikal bebas yang disebabkan oleh stadium dan jenis diferensisi sel yang buruk menyebakan kadar antioksidan yang rendah dalam darah. Gangguan pertahanan sel dan proses karsinogenesis itu sendiri menyebabkan penurunan sintesis antioksidan. Hal ini sejalan dengan penelitian yang yang dilakukan oleh Demirci et al didapatkan pada pasien kanker serviks terjadi perubahan status antioksidan, namun tidak jelas apakah perubahan ini akibat proses karsinogenesis atau akibat paparan kemoterapi. Aktivitas CAT tinggi sebelum dan menurun sesudah kemoterapi pada pasien kanker serviks. Level enzim Catalase kembali normal 6 bulan setelah terapi. Normalisasi aktivitas enzim ini menunjukkan efikasi terapi. Penelitian Manoharan et al melaporkan adanya peningkatan peroksidasi lipid dan pengurangan aktivitas antioksidan enzimatik pada eritrosit pasien kanker serviks. ${ }^{(13)}$

Penurunan kadar antioksidan total pada penelitian ini terkait dengan penurunan berbagai jenis antioksidan dalam serum termasuk Superoxide Dismutation (SOD), seng $(\mathrm{Zn})$, tembaga $(\mathrm{Cu})$ disebabkan oleh pembentukan radikal bebas yang menyebabkan kerusakan pada enzim sebab antioksidan seperti $\mathrm{Zn}$ dan $\mathrm{Cu}$ merupakan kofaktor enzim sehingga merusak DNA inti DNA cross-linking yang menyebabkan mutasi. ${ }^{(14)}$

Kelemahan penelitian ini adalah penelitian ini tidak menilai efek dari agenagen kemoterapi terhadap kadar antioksidan total serta parameter hemopoetik lain sebelum dan setelah kemoterapi sehingga dapat menjadi bahan acuan untuk melihat respon terapi yang nantinya dapat digunakan sebagai prediktor keberhasilan terapi kedepan.

\section{Kesimpulan}

Berdasarkan penelitian ini dapat disimpulkan bahwa pada kanker serviks stadium lanjut, kadar antikoksidan total setelah dilakukan kemoterapi lebih rendah dari pada sebelum 
dilakukan kemoterapi.

\section{Daftar Pustaka}

1. Demirci S, Ozsaran Z, Celik HA, et.al. The interaction between antioxidant status and cervical cancer: a case control study. Department of Medical Biochemistry, Ege University Faculty of Medicine, Bornova, Turkey, 2011: 97; 290-295.

2. World Health Organization.Cancer (online). 2018. available at : www.who. int/mediacentre/fatsheets/fs29

3. Pusat data dan informasi, Situasi Penyakit Kanker. Buletin Pusat Data dan Informasi, Kemenkes RI, 2015.

4. Kementerian Kesehatan Republik Indonesia. Kanker Serviks. Pedoman Nasional Pelayanan Kedokteran. Komite Penanggulangan Kanker Nasional. Jakarta: Kementerian Kesehatan Republik Indonesia, 2018.

5. Murray RK, Granner DK, Rodwell VW. Biokimia Harper, (Andri Hartono). Edisi 27. Jakarta: EGC, 2009.

6. De Sanjose S, Quint WGV, Alemany L, Geraets DT, Klaustermeier JE. Human papillomavirus genotype attribution in invasive cervical cancer: a retrospective cross-sectional worlwide study. The Lancet Oncology, 2010; 11(11).

7. De Boer MA, Vet JN, Aziz MF, et al. Human papillomavirus type 18 and other risk factors for cervical cancer in Jakarta, Indonesia. Int J Gynecol Cancer. 2006; 16: 1809-14.

8. Paramita S, Soewarto S, Widodo MA, Sumitro SB. High parity and hormonal contraception use as risk factors for cervical cancer in East Kalimantan. Med J Indones 2010; 19: 268-2 72.

9. Kirwan JM, Symonds P, Green JA, Tierney J, Col- lingwood M, Williams CJ. A systematic review of acute and late toxicity of concomitant chemoradiation for cervical cancer. Radiother and Oncol, 2003;68:217
10. Jhonsons, O'Dwyer $\mathrm{P}$, Cisplatin and its analogue. In: Devita V, Hellmens, Rossenberg, editors. Cancres Principles and Practice oncology. $7^{\text {th }}$ edition. Philadelphia. Lippincott., 2005: 344-54.

11. Petignat P, Roy M. Diagnosis and management of cervical cancer. BMJ. 2007; 335(7623).

12. Dayem AA, Choi HY, Kim JH, Cho SG. Role of oxidative stress in stem, cancer, and cancer stem cells. Cancer. 2010; 2:859-84.

13. Shanmugan, M., Kolanjiappan, K., Kayalvizhi, M., dan Sethupathy, S. Lipid Peroxidation and Antioxidant Atatus in Cervical Cancer Patient. The Journal of Biochemistry Molecular Biology and Biophysics. 2002; 6(3): 225-227.

14. Naidu MS, Suryakar AN, Swami SC, et al. Oxidative Stress and antioxidant status in cervical cancer patients. Indian J Clin Biochem. 2007; 22(2): 140-144. 